Henryk Sobolewski

Poznan School of Logistics

e-mail: henryk.sobolewski@wsl.com.pl

Jacek Woźniak

Military University of Technology

e-mail: jacekj.wozniak@wat.edu.pl

\title{
MARKET AND REGULATORY RISK IN CREATIVE INDUSTRIES
}

\begin{abstract}
Background: Creative industries - also in Poland - in the 21st century are becoming increasingly important. A dynamic increase is visible in the benefits provided by creative industries through creative good (including services) in individual national economies and in the increase in the level of employment in creative professions. The relevance of research in the indicated area is also determined by the increasing role and importance of identifying risk factors and managing risk in the specified category of enterprises. The objective of this article is to identify the main risk factors related to the operation of innovative enterprises in creative industries in Poland in the areas of market and regulatory risk. The chapter also aims to identify risk perception by the owners or managers of this category of enterprises in the development of innovative activities.
\end{abstract}

Methods: Induction and deduction approach has been applied in the following empirical study The study has also applied methods of analysis and synthesis. The induction approach has been based on the CATI survey technique. The empirical data analysis has also used the k-mean method. The study has been conducted on a sample of 200 enterprises belonging to the creative services subsector.

Results: Enterprises from creative industries attempt to identify the basic risk factors and incorporate them into innovative processes. In the surveyed enterprises, market and regulatory risks deserve particular attention. The key role in assessing these risk include: the relationship with stakeholders (mainly customers), adapting to regulation, as well as taking "competitive fight". Risk is primarily a component of operational management and is usually regarded as a source of opportunities and threats.

Sobolewski H., Woźniak J., Market and Regulatory Risk in Creative Industries [in:] Adamczak M. et al., Digitalization of Supply Chains, Spatium, Radom 2019, p. 117-135. https://doi.org/10.17270/B.M.978-83-66017-86-3.9 
Conclusion: Market and regulatory risk in creative industries are not always perceived as a "driving force" in developing and implementing innovations, but perceived as a business management component. Therefore, the further research should identify the basic principles and guidelines for developing a risk management system in the surveyed category of enterprises - in order to streamline innovation processes.

Key words: market risk, regulatory risk, creative industries, modern enterprise, innovative processes.

\section{INTRODUCTION}

The activities of today's enterprises highlight the role of risk - especially as a source of threats, but also the development opportunities. Risk is not just a factor which entrepreneurs and employees have to undertake a "fight" or to avoid it. Risk is taken consciously, counting on tangible business and organizational benefits. The approach to risk management is not determined only by the potential (i.e. capabilities and constraints) of the company and the peculiarity of its stakeholders, but also the scope of operation. The following empirical research focuses on the activities of the so-called creative industries that are oriented on the development and implementation of innovations in the area of broadly understood culture [Creative Industries Mapping Document: Background 2001]. Creative industries are understood (by The Department for Culture, Media and Sport-DCMS) as an economic activity, encompassing the area of creative activities of people, aimed at the creation and commercialization of culture products, especially in the form of services [based on: Creative Industries Mapping Document: Background 2001].

The main objective of this article is to identify basic risk factors related to the operation of innovative enterprises in creative industries in Poland concerning market and regulatory risk, as well as to specify the perception of risk in the development of innovative activities. The research questions are as follows:

RQ 1: What are the main and most important risk factors (in the area of market and regulatory risks) in creative industries in Poland?

RQ 2: What are the sources of the strategic risk in innovative enterprises in creative industries in Poland?

RQ 3: How is risk perceived by managers in innovative enterprises in creative industries in Poland?

Sobolewski H., Woźniak J., Market and Regulatory Risk in Creative Industries [in:] Adamczak M. et al., Digitalization of Supply Chains, Spatium, Radom 2019, p. 117-135.

https://doi.org/10.17270/B.M.978-83-66017-86-3.9 
RQ 4: How is risk (particularly market and regulatory one) placed in the development of innovative enterprises in creative industries in Poland?

\section{THE ESSENCE OF RISK IN THE OPERATION OF MODERN INNOVATIVE ENTERPRISES}

The activities of modern enterprises are linked to the need to cope with the volatile and unstable environment conditions [Walecka 2018]. Some of these factors have a positive impact on the broadly understood state of the company, others in turn have negative impact [Wu 2006, Vasauskaite 2013] These factors can be considered as sources of risk for current and long-term business activities [Albuquerque, Gomes Couto and Lotti 2019]. These are particularly relevant for the implementation of innovative activities, which is the basis for shaping business models [Dertouzos 1999, Kraus et al. 2018]. This is mainly due to the fact that companies, and in particular so-called creative workers should be able to identify the factors that offer the opportunity for planned and structured creation of values for the different category of stakeholders of innovative processes. The skillful identification and management of these factors is the base of the development of innovative enterprises [Özoğlu and Bülbül 2013, Arasanmi 2019].

Therefore, it is necessary to consider what the risk is and how it should be perceived in modern companies, especially those involved in innovative projects. The literature, does not offer a single and universal definition of risk. However, it can be observed that most of the approaches underline that the risk is mainly a source of losses [Sun, Chen and $\mathrm{Hu} 2018$, Hrytsenko et al. 2019, Montford, Leary and Nagel 2019]. At this point, however, it should be stressed that risk does not always have to be identified with hazards and losses. According to the so-called modern mainstream research, risk is the basis for identifying and lending opportunities [Mader 2011, Krysiak 2011, Board 2011, McNally 2015, Jajuga 2015, Wysocki 2017, ISO 31000:2018] - which should be a contemporary standard in innovative enterprises.

Combining different risk definitions and approaches to risk management, it can be assumed that risk is a probability of achieving or not achieving the intended objective, i.e. the success or failure [Zawiła-Niedźwiecki and Staniec 2008, Zaskórski 2012]. In addition, defining risks and interpreting risk management processes, the operational (short term) and strategic (long term) horizon must be take into account [Wojtysiak-Kotlarski 2011, Frigo and Anderson 2012]. This

Sobolewski H., Woźniak J., Market and Regulatory Risk in Creative Industries [in:] Adamczak M. et al., Digitalization of Supply Chains, Spatium, Radom 2019, p. 117-135. https://doi.org/10.17270/B.M.978-83-66017-86-3.9 
is because risk and risk management should "penetrate" the entire company. In addition, the identification of risk cannot constitute an objective in itself, "detached" from the context and peculiarity of the company's entire operation [McNally 2015]. The risk identification should be a deliberated and legitimated activity, e.g. aimed at increasing effectiveness and efficiency of innovative activities.

To summarize the above considerations, it should be noted that, in this study, authors accept the definition of risk by J. Woźniak [2019], as follows: "risk is a measure of the likelihood that planned and developed innovations will or will not be correctly implemented and/or commercialized in the environment, resulting in measurable benefits (incomes) or risks (losses) for the company, resulting in an increase or decrease in the value created for this company and/or its stakeholders" [Woźniak, 2019].

Considering the activities of enterprises based on innovative processes (especially in creative sectors), it is worth emphasizing that they are strongly geared to the development of activities under a highly competitive market [Boix, Hervás-Oliver and De Miguel-Molina 2015, Lee 2015, Buljubašić, Borić and Hartmann Tolić 2016, Porfírio, Carrilho and Mónico 2016]. In addition, creative activities are determined by a series of legal regulations, e.g. related to the patent protection, trade secret protection, design requirements and user safety standards, as well as time and working conditions, etc. [Hennekam and Bennett 2016, Patten 2016]. Both of these groups of factors are interconnected, with a strong determination of the ability of innovative companies to create competitive advantages and to provide the value to stakeholders. Therefore, the categories of market and regulatory risks will be described in further parts of this article. It is worth noting, however, that other risk categories are also important in the activities of innovative enterprises (also from creative sectors), e.g. financial, socio-cultural, technological, etc. [Wiryono et al. 2015, Strazdas and Cerneviciute 2016, Woźniak 2017] - which are particularly in the interest of researchers. Market and regulatory risks are somewhat depreciated and regarded as less important in the operation of creative industries. On the other hand, market and regulatory risks can be considered as "meta-categories of risk" for modern innovative companies, which are a "derivative" of other (i.e. more "popular") risk classes.

In the operation of modern innovative enterprises, including creative industries, a number of different risk factors can be identified (both opportunities and threats). Basic methodical and resource limitation (e.g. in human and financial aspects) is the inability to identify and manage

Sobolewski H., Woźniak J., Market and Regulatory Risk in Creative Industries [in:] Adamczak M. et al., Digitalization of Supply Chains, Spatium, Radom 2019, p. 117-135.

https://doi.org/10.17270/B.M.978-83-66017-86-3.9 
the majority of risk factors [Nowak and Sobolewski 2017]. Companies wishing to concentrate on the core business (i.e. innovation processes and the creation of value for stakeholders) identify and monitor the basic risks. This is often the case of the so-called "silo" (i.e. classic) approach to risk management in innovative entities in creative industries [Woźniak, 2019]. In micro- and small-sized enterprises operating in modern industries and sectors, the silo approach may be sufficient (but it is not a rule), and the formation of the so-called "informational islands" does not need to hinder risk management processes. Therefore, it is not surprising that in this category of companies, there may be a concentration on general risk categories, particularly market and regulatory ones. On the other hand, in medium- and large-sized innovative companies such activities may be insufficient [Sobolewski and Marcinkowski 2017].

The regulatory risk mainly concerns the evolution of legal provisions, and also leads to the possibility of pursuing obligations on counterparties and outstanding debts by external entities [Kasiewicz 2017, Kasiewicz 2018, Lewis 2018, Gueyié, Guidara and Lai 2019, Adler 2019]. In turn, the market risk is a consequence of achieving the company's objectives in the economy and relationships between the environment and the company. It is associated with changes in the price of assets and contracts, as well as affects the financial flows. It refers e.g. to such subcategories as interest rate risk, commodity and stock prices, exchange rate, as well as business and non-commercial relations on the market [Zaskórski et al. 2015, The Future of Risk Management in the Digital Era 2017]. It is also worth noting that the innovativeness of modern companies operating in creative industries can be strengthened by the successive development of innovative processes aimed at developing both the creative potential of workers and increasing the value of the effects provided to customers, and thus to entities operating on the broadly understood market [Sobolewski and Wściubiak 2017]. The market risk is therefore a specific "bridge" between innovative processes, and capabilities, requirements, needs and constraints of customers.

In conclusion, it can be noted that market and regulatory risk can have a significant impact on the activities of today's innovative enterprises, including creative industries. On one hand, identified risk areas require the implementation of adaptative and improving actions, which may have a positive impact on innovative processes. On the other hand, these areas offer specific limitations in the development of this category of enterprises, being e.g. a source of 
costs. The enterprises' approach to market and regulatory risk will be explored further in the following chapter - based on an analysis of results of the empirical study.

\section{METHODOLOGY OF THE EMPIRICAL RESEARCH}

The empirical study has used an induction approach. The study also has applied elements of a deduction approach, mainly in analysis of national and foreign literature. It should be stressed, however, that an induction approach has had a leading role. The study also has used methods of analysis and synthesis - as a consequence of combining deductive (literature analysis and theoretical inference) and induction (analysis of individual cases) approaches. The induction approach has applied the CATI survey technique. The analysis of empirical data also has used the $k$-mean method. In this case, it has been applied the hierarchical cluster analysis agglomerative method (tree diagram, Ward method). Euclidean distance has been included as a basic metric [based on: Hartigan and Wong 1979, StatSoft 2006, Kajstura 2019].

The empirical study $(N=200)$ has focused on the peculiarity of risk management in innovative processes in project enterprises from the creative services' subsector - according to the classification of DCMS [see: Kasprzak 2013]. The following PKD numbers have been qualified for the study: 62.01.Z - software, 71.11.Z - architecture, 73.11.Z - advertising, as well as $74.10 . Z$ - design.

The study has included mainly the project enterprises where innovative activities are dominant. The study has used a systematic random sampling (taking into account the criterion of the leading PKD activity profile in the creative industries) in layers (the layers have been determined taking into account the size of the company according to the number of employees) - reflecting the quantitative structure of enterprises in the population. In each PKD class, the number of entities has been equal, i.e. $N=50$ (Table 1 ). This has been primarily used in order to compare companies between all 4 classes and identify fundamental differences and similarities in the risk management in innovation processes between these categories of enterprises. This internal structure of the research sample for the CATI study is acceptable taking into account the lack of full representability of the sample.

Table 1. Specification of the research sample in terms of the leading business profile criterion

\begin{tabular}{|l|c|c|c|c|c|c|c|c|c|}
\hline \multirow{2}{*}{$\begin{array}{l}\text { Basic criteria for specification } \\
\text { of the research sample }\end{array}$} & \multicolumn{4}{|c|}{ Leading business profile - PKD } & \multicolumn{3}{|c|}{ Total } \\
\cline { 2 - 10 } & $62.01 . \mathrm{Z}$ & $71.11 . \mathrm{Z}$ & $73.11 . \mathrm{Z}$ & $74.10 . \mathrm{Z}$ & \multicolumn{2}{|c|}{} \\
\cline { 2 - 10 } & $\mathrm{N}^{*}$ & $\% * *$ & $\mathrm{~N}$ & $\%$ & $\mathrm{~N}$ & $\%$ & $\mathrm{~N}$ & $\%$ & $\mathrm{~N}$ \\
\hline
\end{tabular}

Sobolewski H., Woźniak J., Market and Regulatory Risk in Creative Industries [in:] Adamczak M. et al., Digitalization of Supply Chains, Spatium, Radom 2019, p. 117-135.

https://doi.org/10.17270/B.M.978-83-66017-86-3.9 


\begin{tabular}{|c|c|c|c|c|c|c|c|c|c|c|}
\hline \multicolumn{11}{|c|}{ Age of enterprise } \\
\hline $\begin{array}{l}\text { Less than } 10 \text { years } \\
\text { ("relatively young") }\end{array}$ & 26 & 13 & 15 & 7.5 & 12 & 6 & 18 & 9 & 71 & 35.5 \\
\hline 10-15 years old ("mature") & 7 & 3.5 & 19 & 9.5 & 21 & 10.5 & 15 & 7.5 & 62 & 31 \\
\hline $\begin{array}{l}\text { More than } 15 \text { years } \\
\text { ("relatively old") }\end{array}$ & 17 & 8.5 & 16 & 8 & 17 & 8.5 & 17 & 8.5 & 67 & 33.5 \\
\hline \multicolumn{11}{|c|}{ Size of enterprise } \\
\hline Micro ( $1-9$ employees $)$ & 47 & 23.5 & 49 & 24.5 & 47 & 23.5 & 49 & 24.5 & 192 & 96 \\
\hline $\begin{array}{l}\text { Small, medium and large } \\
(\geq 10 \text { employees })\end{array}$ & 3 & 1.5 & 1 & 0.5 & 3 & 1.5 & 1 & 0.5 & 8 & 4 \\
\hline \multicolumn{11}{|c|}{ Level of average annual turnovers } \\
\hline Less than 40 million PLN & 19 & 9.5 & 21 & 10.5 & 24 & 12 & 29 & 14.5 & 93 & 46.5 \\
\hline$<40-100 \mathrm{mln}$ PLN) & 12 & 6 & 6 & 3 & 11 & 5.5 & 7 & 3.5 & 36 & 18 \\
\hline$<100-170 \mathrm{mln}$ PLN) & 2 & 1 & 4 & 2 & 3 & 1.5 & 0 & 0 & 9 & 4.5 \\
\hline $170 \mathrm{mln}$ PLN and more & 0 & 0 & 0 & 0 & 0 & 0 & 2 & 1 & 2 & 1 \\
\hline Refusal to respond & 17 & 8.5 & 19 & 9.5 & 12 & 6 & 12 & 6 & 60 & 30 \\
\hline \multicolumn{11}{|c|}{ Scale of the business activity } \\
\hline $\begin{array}{l}\text { Local } \\
\text { (1 town/municipality/district) }\end{array}$ & 12 & 6 & 11 & 5.5 & 10 & 5 & 22 & 11 & 55 & 27.5 \\
\hline $\begin{array}{l}\text { Regional } \\
\text { (1-8 voivodships in Poland) }\end{array}$ & 9 & 4,5 & 8 & 4 & 14 & 7 & 8 & 4 & 39 & 19.5 \\
\hline $\begin{array}{l}\text { National } \\
\text { (9-16 voivodships in Poland) }\end{array}$ & 25 & 12.5 & 28 & 14 & 22 & 11 & 16 & 8 & 91 & 45.5 \\
\hline $\begin{array}{l}\text { European (at least } 1 \text { country } \\
\text { in Europe outside of Poland) }\end{array}$ & 1 & 0,5 & 1 & 0.5 & 2 & 1 & 0 & 0 & 4 & 2 \\
\hline $\begin{array}{l}\text { International (at least } 1 \text { country } \\
\text { in the world outside Europe, } \\
\text { including outside of Poland) }\end{array}$ & 3 & 1,5 & 2 & 1 & 2 & 1 & 4 & 2 & 11 & 5.5 \\
\hline Total & 50 & 25 & 50 & 25 & 50 & 25 & 50 & 25 & 200 & 100 \\
\hline
\end{tabular}

* Number of enterprises. ** Percentage of companies in the research sample.

Source: own elaboration based on [Woźniak, 2019] (N=200).

According to Table 1, micro enterprises - $96 \%$ of the surveyed units dominate in the research sample. The structure of the entire population of enterprises belonging to the subsector of creative services in Poland has a similar structure [Grochowski et al. 2012, Szara and Wojtowicz 2016]. In this study, the most of companies have been relatively young, i.e. operated in the market less than 10 years (35.5\% of enterprises). The majority of the surveyed companies have carried out activities at the national scale $-45.5 \%$, and at least at European scale $-2 \%$, as well as the international scale $-5.5 \%$. Among the surveyed companies the largest share have had the business units with the average level of the annual turnover lower than PLN 40 million (46.5\% of enterprises). It is worth highlighting that $30 \%$ of respondents have refused to answer the question about the average level of annual turnovers - regarding it as "sensitive" data protection (Table 1).

\section{RESULTS OF THE EMPIRICAL RESEARCH}

Taking into account the purpose of the study, i.e. the specification of the risk perception by the owners or managers in the development of innovative activities, it is worth noting that the

Sobolewski H., Woźniak J., Market and Regulatory Risk in Creative Industries [in:] Adamczak M. et al., Digitalization of Supply Chains, Spatium, Radom 2019, p. 117-135. https://doi.org/10.17270/B.M.978-83-66017-86-3.9 
majority of respondents in the whole research sample (49\%) share the opinion that risk is the source of both benefits and threats. Such an "universal" and somewhat "modern" approach to risk and risk management also prevails in all 4 categories of creative/innovative service activities. It should be noted, however, that a significant percent of respondents perceives risk mainly in terms of potential losses $-39 \%$. However, it is hopeful that, in spite of above observations, practically every tenth respondent is convinced that risk is above all the source of potential benefits (Figure 1).

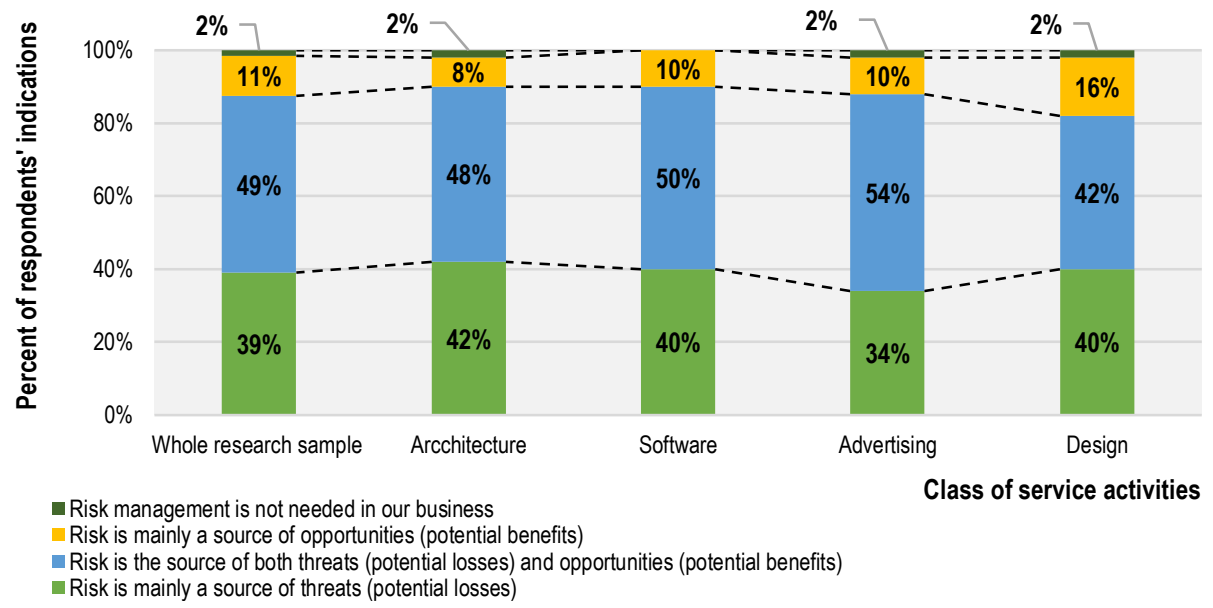

Fig. 1. Number of indications of respondents on the approach to risk perception (single choice question).

Source: own elaboration $(N=200)$.

This risk perception offers a fairly good organizational and managerial basis for the correct and "modern" implementation of innovative processes. This is due to the fact that e.g. with the identification, validation and evaluation of opportunities and threats, companies can develop a relatively accurate picture of the decision-making situation [Zaskórski 2012]. This is particularly important when it is necessary to meet the requirements of new markets' segments that are not yet adequately penetrated [Sobolewski and Wściubiak 2017, Wysocki 2017]. In addition, risk perception in terms of opportunities enables workers in the creative industries to make a brave and proactive impact on certain stakeholder categories, thus to progressively "acquire" new markets [Wereda and Woźniak, 2019]. Innovations in globalized business circumstances need "courage" and "brave thinking" - and this attitude requires a particular "risk appetite", which can be defined as the level of risk that the company is "willing" to take in order to attain the objectives' set [see: Anderson 2011]. "Closing" in the context of risk thinking as a 
source of losses on the one hand reduces the likelihood of making mistakes, and the loss of valuable resources, while on the other hand it limits the creative potential of workers and closes the company in a specific "low-innovation trap" [Wojtysiak-Kotlarski 2011, McNally 2015, Woźniak 2019].

On the basis of the above results, it can be simplified that risk in the opinion of respondents may be of relevance in the development of innovative activities - this does not have to be a strong impact, but it is, in principle, observed by employees and managerial staff. Respondents recognize the opportunity to manage risk and the overall potential to improve innovation processes. Here, however, it is worth focusing on market and regulatory risk. The most important market risk factors are: increasing competition on the market (22\% of respondents' indications), inability to attract and/or maintain customers (9\%), as well as the unreliability/disloyalty of customers (4\%), and a change in the price of goods (4\%). On the other hand, in the area of regulatory risk, the most important risk factors are: the need to adapt to regulatory requirements $(7 \%)$, and weaknesses of regulations already implemented and applied (6\%) (Figure 2).

The above results also indicate that innovative activities on the market are linked, in particular, to one specific group of stakeholders - customers. Noteworthy is the fact that customers are, on the one hand, orderers and consumers of innovations (in the form of a service), and on the other hand are perceived as one of the most unreliable elements of the innovative process. This situation is important, because today, also in the creative industries, it is a popular practice to use prosumption and exploit the potential of the so-called 4.0 customers [Wereda and Woźniak 2019]. It is worth considering the scale and scope of integrating customers into innovative processes. The question that arises is as follows: Is participation of a modern customer in innovative processes really necessary and can guarantee value not only for that customer but also for the company itself and for other stakeholder groups? Reflecting on the participation of customers with innovative processes, it is essential to link the phenomenon of customer disloyalty, their low engagement, and the demanding attitude with strong competition in the industry [based on: Wu 2006, Lee 2015, Porfírio, Carrilho and Mónico 2016, Wereda and Woźniak 2019]. Another question arises: Are customers able to guarantee the company a peculiar "element of uniqueness" that will allow to fight with other players on the 
market, or "only" to survive? Therefore, it is worth considering whether customers are always an effective and efficient source of values' creation in innovative processes [Patten 2016].

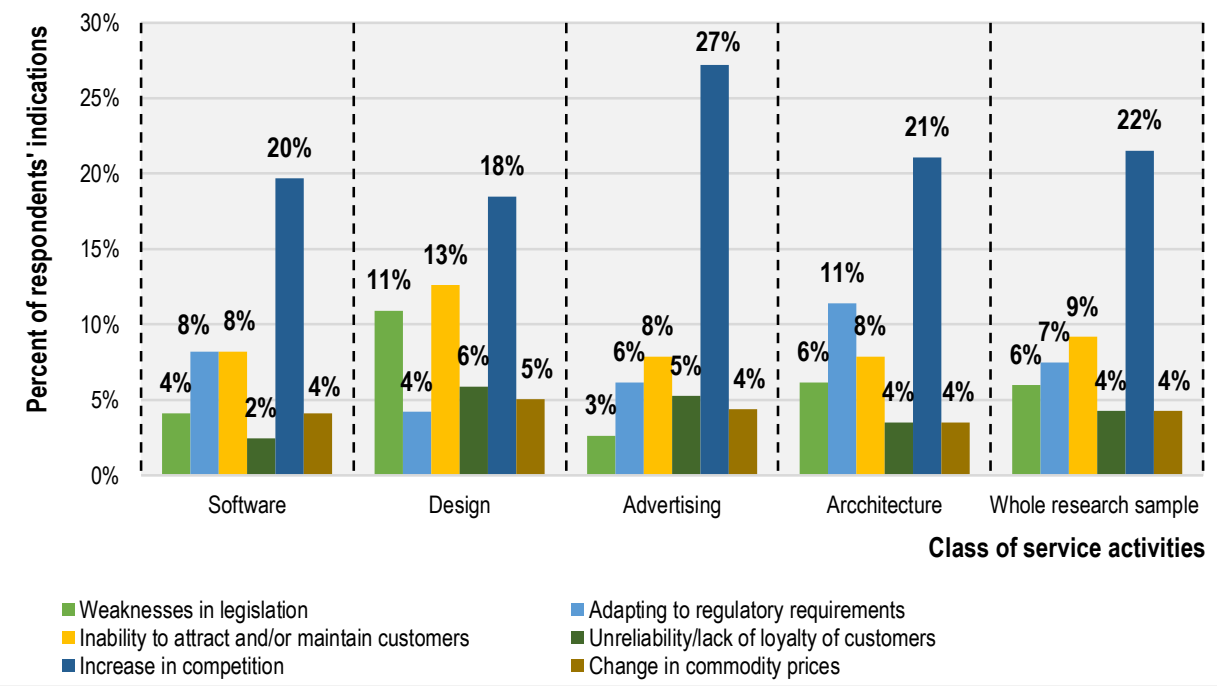

Fig. 2. Percentage of respondents' indications of the most important risk factors related to business activity (multiple choice question).

Source: own elaboration $(N=200)$.

In innovative processes, expenditures are of key importance - and customer relationships are also an important source of costs [Wereda and Woźniak 2019]. Assuming that respondents treat commodity price changes as a relatively important market risk factor in innovative processes, cost optimization is necessary. Therefore, in the event of an increase in the cost of purchasing goods (as well as external services and raw materials to creative processes), it is necessary to minimize other cost groups, e.g. of stakeholder relationships [Özoğlu and Bülbül 2013, Arasanmi 2019]. The need to choose between areas of investment in innovative processes is a major challenge for executives and business owners in creative industries [Szara and Wojtowicz 2016]. Each activity and resource can be the basis for creating value throughout the innovation's lifecycle, and it is not always possible to estimate the level of this value in ex ante approach [Sobolewski and Wściubiak 2017]. An additional challenge is the need to meet the requirements of the digitalization of economic activities, as well as the "networking/opening" of implementation of innovative processes, and to bear the associated costs [The Future of Risk Management in the Digital Era 2017].

Sobolewski H., Woźniak J., Market and Regulatory Risk in Creative Industries [in:] Adamczak M. et al., Digitalization of Supply Chains, Spatium, Radom 2019, p. 117-135.

https://doi.org/10.17270/B.M.978-83-66017-86-3.9 
The need to adapt to regulatory requirements and weaknesses in already implemented and applied regulations can also determine the scale and scope of stakeholder relationships (mainly external stakeholders), as well as taking the "competitive fight" by creating competitive advantages [based on: Kasiewicz 2018]. In innovative activities, especially in creative sectors, the protection of intellectual property deserves special attention, which is the direct basis of the creation of innovation, as well as the "mystery" and "potential" of the company [Kasprzak 2013, Szara and Wojtowicz 2016]. Regulations, despite the fact that they define the conditions of actions for innovative enterprises, also open up a specific "range" of possibilities for interpreting certain provisions. Those who skilfully "read" the chances of regulation (or, in fact, inaccuracies in the legislation) increase their competitive potential [Lewis 2018, Adler 2019]. On the other hand, it is a threat, because it causes a violation of "competitive balance" in the industry and the emergence of various "pathologies" of economic activities [based on: Kasiewicz 2018].

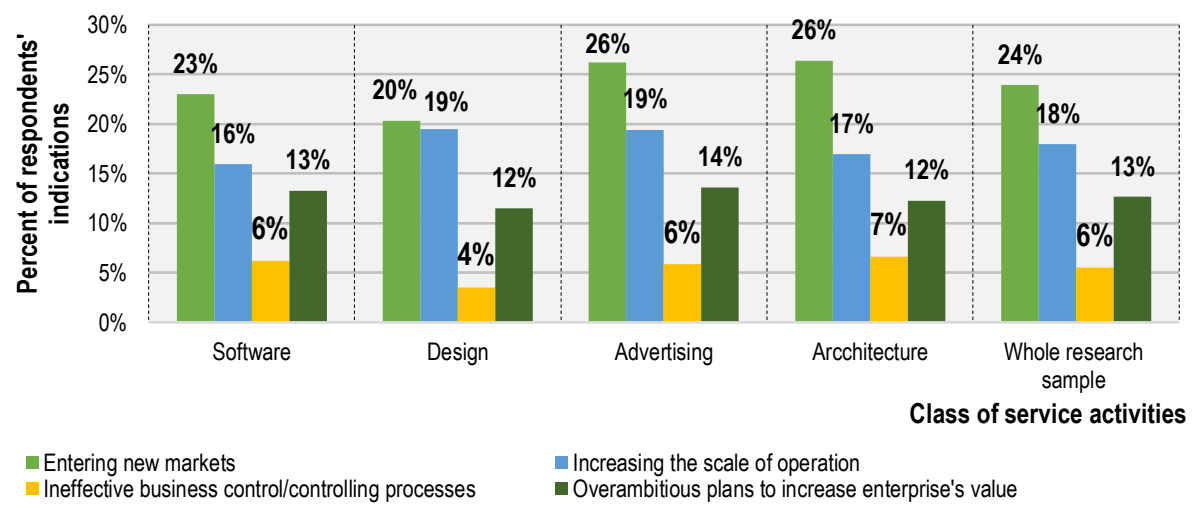

Fig. 3. Percentage of respondents' indications of sources of the strategic risk (multiple choice question).

Source: own elaboration $(N=200)$.

The key market and regulatory risk factors oscillate the relationships with customers and co-operatives (e.g. with the use of modern ICTs), taking a competition battle (or coopetition) with competitors, as well as the skills of "smart" adaptation to implemented regulations, e.g. in the field of intellectual property protection, business conducting (primarily related to raising of finance for innovative activities), or the management of human resources (so-called creative workers) [based on: Wereda and Woźniak 2019]. However, these risk factors refer to the current operations of companies. In order to manage risks effectively and efficiently (as a source of both opportunities and threats), there is a need to conduct a strategic/long-term analysis 
[Zawiła-Niedźwiecki and Staniec 2008]. A fundamental question arises: What can be the main sources of strategic risk in the development of innovative enterprises in creative industries?

According to respondents' opinions, the biggest importance concerning market and regulatory risk is dedicated to entering new markets (24\% of respondents' answers), and increase the scale of operations $(18 \%)$. However, less relevance in respondents' opinion is that the company's plans are too ambitious to increase its value (13\%), and ineffective control processes (6\%) (Figure 3). It can be noted that, respondents, indicate more importance in the long-term development of innovative enterprises is the source of external risk, which is linked to the need to adapt to new, unknown and thus poorly predictable environmental conditions. External risk is associated to identification of different customer requirements, other antitrust laws, or specific restrictions on customer protection and creative activities. Less relevance to respondents is the risk source determined by employees and managers of companies. This may be the result of respondents' opinion/belief that internal risk sources are under greater control of employees and are more easily planned and possibly modified in the long term without exposing the enterprise and processes on additional costs and mistakes - which, however, does not always have to be true, especially in innovative service activities.

Table 2. Clusters of enterprises in the framework of the peculiarity and subject scope of risk factors relevant to the development of innovative activities

\begin{tabular}{|c|c|c|c|}
\hline \multicolumn{2}{|r|}{ Name of cluster } & Experiencing regulatory risk & Experiencing market risk \\
\hline \multicolumn{2}{|r|}{ Abundance of clusters } & 47 & 27 \\
\hline \multirow{7}{*}{ 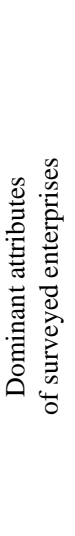 } & Size & \multicolumn{2}{|c|}{ micro enterprises } \\
\hline & PKD & 62.01.Z & $74.10 . Z$ \\
\hline & Age & "relatively old" & "relatively young" \\
\hline & $\begin{array}{l}\text { Level of average annual } \\
\text { turnovers }\end{array}$ & 0-10 mln PLN & 10-40 mln PLN \\
\hline & Scale of operation & national & regional \\
\hline & $\begin{array}{l}\text { Impact of risk management } \\
\text { on the enterprise }\end{array}$ & moderate & low \\
\hline & Risk perception & source of threats & $\begin{array}{l}\text { source of opportunities } \\
\text { and threats }\end{array}$ \\
\hline
\end{tabular}

Source: own elaboration $(N=200)$.

Sobolewski H., Woźniak J., Market and Regulatory Risk in Creative Industries [in:] Adamczak M. et al., Digitalization of Supply Chains, Spatium, Radom 2019, p. 117-135.

https://doi.org/10.17270/B.M.978-83-66017-86-3.9 
It can be assumed that respondents tend to recognize the need to take into account regulatory and market risk management in the development of innovative activities, but do not always introduce it into business practice. It is interesting to notice which type of innovative enterprises are oriented at managing the risk areas identified above. The study has identified the clusters of enterprises (with the use of the $k$-mean method), which focuses mainly on the market or regulatory risk (Table 2).

Among the companies which recognize regulatory risk, are found mainly the entities having up to 9 employees (micro organizations) and operating on the market for more than 15 years, and with relatively low annual turnovers (up to PLN 10 million). These companies operate mainly in a national scale, and risk is regarded as a source of threats. In turn, the impact of risk management on innovative processes in this group of companies is perceived to possess a moderate level. This situation may be due mainly to the fact that the companies belonging to this cluster primarily deal with software activities. It is a fairly stable market, especially in a national scale, where no risk factors exist that can "surprise" entrepreneurs and disrupt the stability and continuity of innovative processes. In this type of creative activity, certain legal provisions are quite important, especially those related to the protection of intellectual property and the rules of commercial and civil law. However, these regulations, despite the high importance for businesses in operating activities, do not change rapidly (especially in a national scale) and do not "threaten" innovative processes. Regulatory risk is mainly regarded as a source of potential losses, as the company-relevant regulations are not a source of broadly understood benefits (e.g. financial ones). It is also worth noting that companies from this cluster, thanks to their market experience, as well as relatively small scale of operation and process complexity, are rather "resilient" to changes in regulation (Table 2).

In contrast, the second cluster (enterprises focused on the market risk) is mainly collected by design companies. In this cluster, there are also micro organizations, however, operating on the market for a maximum of 10 years. In this cluster, the average annual turnovers are also at a higher level - up to PLN 40 million. Companies in this cluster are mainly active in the regional scale. It is worth noting that risk in this cluster of companies has a low impact on innovative processes, and risk is perceived as a source of both opportunities and threats. Such situation can be explained by the business profile of the enterprises, where the market is mainly a source for searching development opportunities. The investigated entities (mainly aimed at design) 
generally take an active "fight" against competitors and try to provide the highest value to customers, which is derived from the creativity of employees/designers. In this cluster, it is also important that service innovations are implemented only within specific orders. Thus, innovations have predetermined customers who participate in innovative processes - they are the orderers. Therefore, in principle, market risk is not considered to be particularly strong in affecting the core business processes in enterprises in this cluster - despite the fact that these enterprises actively seek opportunity factors and try to neutralize threat factors (Table 2).

\section{CONCLUSIONS}

The activities of enterprises in creative industries relate to the occurrence of various risk factors (in the form of both opportunities and threats). Therefore, this category of enterprises oriented on innovative projects - should progressively incorporate risk management processes into their organizational system. Among different areas and types of risk dedicated to enterprises in creative industries, market and regulatory risks deserve a particular attention which was emphasized in the article. The key role in these areas of risk is dedicated to engaging relationships with stakeholders (in particular customers), adapting to regulations and their dynamics, and undertaking "competitive fight" on the basis of the gained competitive advantages (e.g. intellectual capital, which is particularly important in services).

Summarizing results of this empirical study, it can be noted that the surveyed companies attempt to identify basic risk factors and incorporate them into the company's management system, and in particular in innovative processes. It is also worth remembering that in these enterprises risk is mainly a component of operational management, as well as it is perceived as a source of both opportunities and threats. It is also interesting that strategic management draws attention mainly to external risk factors. The risk is not always seen as the "basic force" of creating values for different stakeholder groups in the surveyed enterprises, but is regarded as a component of the "innovation system".

The limitation of the following study is the size of the research sample $(N=200)$. The second limitation relates to the scope of researched enterprises and their innovative activities. These enterprises belong to the sub-sector of creative services - and, thus, do not embrace all activities included in the creative sectors' classification. Such narrowing of the research scope has been mainly determined by: (1) the necessity of reaching out to enterprises which are standardized 
(financially and organizationally), and are fully commercialized and strongly focused on the creation and implementation of innovations for customers, (2) costs and timeframe of the survey. Moreover, the study is focused only on the Polish area and does not include peculiarities of Polish and foreign creative industries.

In addition, the future research in the specified research area should be linked to the identification of potential relationships between the importance and strength of regulatory risk factors and the value of market risk factors. This "in-depth" analysis could provide the basis for shaping and developing new business models and potential strategies for action in dynamic markets for innovative enterprises in the creative industries in Poland.

\section{REFERENCES}

Adler M.A., 2019. New Litigation and Regulatory Risks. CPA Journal, 89(2), 52-55.

Albuquerque M., Gomes Couto M.H., Lotti O., 2019. Identification and analysis of enterprise risks associated with the value environment of the Cargill cocoa business. Cadernos EBAPE, 17(1), 156-172. DOI: 10.1590/1679-395172203.

Anderson R., 2011. Risk Appetite \& Tolerance: Executive Summary. A guidance paper from the Institute of Risk Management, September.

Arasanmi Ch.N., 2019. Training effectiveness in an enterprise resource planning system environment. European Journal of Training \& Development, 43(5), 456-469. DOI: 10.1108/EJTD-09-2018-0087.

Board J., 2011. Understanding risk. Governance, Issue 204, May.

Boix R., Hervás-Oliver J.L., De Miguel-Molina B., 2015. Micro-geographies of creative industries clusters in Europe: From hot spots to assemblages. Papers in Regional Science, 94(4), 753-773.

Buljubašić I., Borić M., Hartmann Tolić I., 2016. The impact of promotion in creative industries - the case of museum attendance. Ekonomski Vjesnik/Econviews, XXIX(1), 109-124.

Creative Industries Mapping Document: Background, 2001, DCMS, London.

Dertouzos M., 1999. Four pillars of innovation. Technology Review, 102(6).

Frigo M.L., Anderson R.J., 2012, Strategic Risk Management: A Primer for Directors and Management Teams, Montvale, Chicago. 
Grochowski M., Dudek-Mańkowska S., Fuhrmann M., Zegar T., 2012. Sektor kreatywny w województwach pomorskim i kujawsko-pomorskim. Raport z badań [Creative industry in the Pomeranian and Kuyavian-Pomeranian voivodships. Research report], Agencja Rozwoju Pomorza S.A., Gdańsk.

Gueyié J.-P., Guidara A., Lai V.S., 2019. Banks' non-traditional activities under regulatory changes: impact on risk, performance and capital adequacy. Applied Economics, 51(29), 3184-3197. DOI: 10.1080/00036846.2019.1569197.

Hartigan J.A., Wong M.A., 1979. A K-Means Clustering Algorithm. Applied Statistics, 28, 100-108.

Hennekam S., Bennett D., 2016. Self-Management of Work in the Creative Industries in the Netherlands. International Journal of Arts Management, 19(1), 31-41.

Hrytsenko L., Boiarko I., Ryabenkov O., Didenko O., 2019. Assessment of the value loss risk in response to the enterprise's innovative transformations. Marketing \& Management of Innovations, 1, 229-237. DOI: 10.21272/mmi.2019.1-19.

ISO 31000:2018(en): Risk management - Guidelines, International Organization for Standardization, 2018, Geneva.

Jajuga K., 2015. "Risk - basic concepts", in Jajuga, K., Feldman, Ł., Pietrzyk, R., Rokita, P.

(Eds.), Integrated Risk Model in Household Life Cycle, Publishing House of Wrocław University of Economics, Wrocław. 53-60.

Kajstura A., 2019. Metoda k-średnich [k-mean method]. Available on the Internet:

https://www.statystyka.az.pl/analiza-skupien/metoda-k-srednich.php (25/08/2019).

Kasiewicz S., 2017. The role of regulatory risk in the concept of banking sector's selfregulation. Business Administration Quarterly, 42(1), 39-46.

Kasiewicz S., 2018. PSD 2: krytyczny przystanek na drodze do nowej ery bankowości [PSD 2: A critical stop on the way to a new era of banking], Warsaw School of Economics, Warsaw. Kasprzak R., 2013. Przemysły kreatywne w Polsce: uwarunkowania i perspektywy [Creative industries in Poland: Circumstances and prospects], Kamon Consulting, Warsaw.

Kraus S., Kallmuenzer A., Stieger D., Peters M., Calabrò A., 2018. Entrepreneurial paths to family firm performance. Journal of Business Research, 88, 382-387. DOI: 10.1016/j.jbusres.2017.12.046.

Sobolewski H., Woźniak J., Market and Regulatory Risk in Creative Industries [in:] Adamczak M. et al., Digitalization of Supply Chains, Spatium, Radom 2019, p. 117-135.

https://doi.org/10.17270/B.M.978-83-66017-86-3.9 
Krysiak Z., 2011. Silna kultura zarządzania ryzykiem jako cecha nowoczesnych organizacji [A strong risk management culture as a feature of modern organizations]. e-mentor, 2(39), 2432.

Lee M., 2015. Fostering connectivity: a social network analysis of entrepreneurs in creative industries. International Journal of Cultural Policy, 21(2), 139-152.

Lewis M., 2018. Outsourcing, new technologies and new technology risks: Current and trending UK regulatory themes, concerns and focuses. Journal of Securities Operations \& Custody, 10(2), 145-156.

Mader S., 2011., Risk: A Four-Letter Word No More. Directorship, April-May.

McNally J.S., 2015. Risk. Leverage it. Control it. Win!. Pennsylvania CPA Journal, Winter.

Montford W., Leary R.B., Nagel D.M., 2019. The impact of implicit self-theories and loss salience on financial risk. Journal of Business Research, 99, 1-11. DOI: 10.1016/j.jbusres.2019.02.015.

Nowak D., Sobolewski H., 2017. Czynniki stymulujące i destymulujące aktywność innowacyjną przedsiębiorstw - wyniki badań [Stimulants and destimulants of innovative activities of enterprises - research results]. Studia i Prace WNEiZ US, 48(3), 179-191.

Özoğlu B., Bülbül H., 2013. The Reliability and Validity Study of the Motivated Consumer Innovativeness (MCI) and Perceived Risk Scales. Journal of Alanya Faculty of Business, 5(3), 129-139.

Patten T., 2016. “Creative?"... "Entrepreneur?" - Understanding the creative industries entrepreneur. Artivate: A Journal of Entrepreneurship in the Art, 5(2), 23-42.

Porfírio J.A., Carrilho T., Mónico L.S., 2016. Entrepreneurship in different contexts in cultural and creative industries. Journal of Business Research, 69, 5117-5123.

Sobolewski H., Marcinkowski B., 2017. Zarządzanie ryzykiem w praktyce gospodarczej [Risk Management in economic practice]. Studia i Prace WNEiZ US, 50(3), 143-154.

Sobolewski H., Wściubiak Ł., 2017. Innowacje a wyniki przedsiębiorstwa: wybrane aspekty badawcze [Innovations and enterprise's performance: Selected research aspects]. Finanse, Rynki Finansowe, Ubezpieczenia, 1(85), 445-453.

StatSoft, 2006. Elektroniczny Podręcznik Statystyki [Electronic Statistics Handbook]. Available on the Internet: http://www.statsoft.pl/textbook/stathome.html (15/04/2018). 
Strazdas R., Cerneviciute J., 2016. Continuous Improvement Model for Creative Industries Enterprises Development. Transformations in Business \& Economics, 15(2), 46-60.

Sun F., Chen Y., Hu Y., 2018. Set-valued loss-based risk measures. Positivity, 22(3), 859-871. DOI: 10.1007/s11117-017-0550-5.

Szara K., Wojtowicz P., 2016. Sektor kreatywny w Polsce - stan i znaczenie [The Creative Sector in Poland - State and Meaning]. Przedsiębiorstwo i Region, 8, 7-21.

The Future of Risk Management in the Digital Era, 2017. Institute of International Finance, McKinsey\&Company, October.

Vasauskaite J., 2013. Business environment factors determining the selection of time for the implementation of new technologies in Lithuanian industrial enterprises. Economics \& Management, 18(4), 744-753. DOI: 10.5755/j01.em.18.4.5347.

Walecka A., 2018. Analysis of the relationship between the enterprise and the environment in the context of managing the Relational Capital. Management, 22(2), 25-41. DOI:

10.2478/manment-2018-0021.

Wereda W., Woźniak J., 2019. Building Relationships with Customer 4.0 in the Era of Marketing 4.0: The Case Study of Innovative Enterprises in Poland. Social Sciences, 8(6), 1-27. DOI: https://doi.org/10.3390/socsci8060177.

Wiryono S.K. et al., 2015. Risk Mapping on Dynamics Creative Industry. Procedia - Social and Behavioral Sciences, 169, 125-130.

Wojtysiak-Kotlarski M., 2011. "Zmienność, złożoność, niepewność i ryzyko - determinanty współczesnego przedsiębiorstwa" ["Volatility, complexity, uncertainty and risk - the determinants of today's company"], in Kasiewicz, S. (Ed.), Zarządzanie zintegrowanym ryzykiem przedsiębiorstwa w Polsce: kierunki i narzędzia [Management of integrated risk of enterprise in Poland: Directions and tools], Wolters Kluwer, Warsaw. 28-48.

Woźniak J., 2017. Zarządzanie ryzykiem w przedsiębiorstwach projektowych w sektorach kreatywnych. Część 1: Identyfikacja czynników ryzyka [Risk management in design enterprises in creative sectors. Part 1: Identification of risk factors]. Zeszyty Naukowe Uniwersytetu Przyrodniczo-Humanistycznego w Siedlcach. Seria: Administracja i Zarządzanie, 114(41), 225-235.

Woźniak J., 2019. Zarządzanie ryzykiem w sektorach kreatywnych [Risk management in creative industries], CeDeWu, Warsaw.

Sobolewski H., Woźniak J., Market and Regulatory Risk in Creative Industries [in:] Adamczak M. et al., Digitalization of Supply Chains, Spatium, Radom 2019, p. 117-135.

https://doi.org/10.17270/B.M.978-83-66017-86-3.9 
Wu L.-Y., 2006. Resources, dynamic capabilities and performance in a dynamic environment: Perceptions in Taiwanese IT enterprises. Information \& Management, 43(4), 447-454. DOI: 10.1016/j.im.2005.11.001.

Wysocki J., 2017. "Pomiar i ocena ryzyka w przedsięwzięciach typu start-up" ["Measurement and risk assessment in start-ups"], in Kałowski, A., Wysocki, J. (Eds.), Start-up a uwarunkowania sukcesu. Wymiar teoretyczno-praktyczny [Start-up and the determination of a success. Theoretical and practical dimension], Warsaw School of Economics, Warsaw. 149-187.

Zaskórski P., 2012. Asymetria informacyjna w zarządzaniu procesami [Information asymmetry in process management], Military University of Technology, Warsaw.

Zaskórski P., Woźniak J., Szwarc K., Tomaszewski Ł., 2015. Zarządzanie projektami w ujęciu systemowym [Project management in a systemic approach], Military University of Technology, Warsaw.

Zawiła-Niedźwiecki J., Staniec I. (Eds.), 2008. Zarządzanie ryzykiem operacyjnym [Operational risk management], C.H. Beck, Warsaw 